\title{
СТРАТЕГІЧНЕ ДЕРЖАВНЕ УПРАВЛІННЯ ІННОВАЦІЙНИМ РОЗВИТКОМ ТРАНСПОРТНОЇ ІНФРАСТРУКТУРИ
}

\section{Дмитрієва О.І., доктор екон. наук, доцент}

Харківський національний автомобільно-дорожній університет

\section{Тімров О.О., молодший науковий співробітник}

Науково-дослідний, проєктно-конструкторський та технологічний інститут мікрографії. м. Харків, Украӥна.

Постановка проблеми. В сучасних умовах ключовим завданням України щодо рівноправного, конкурентоспроможного партнерства в системі міжнародних торговельно-економічних зв'язків $€$ забезпечення якісної трансформації наявної в країні інфраструктури транспорту, що виступає важливим учасником міжнародних логістичних ланцюгів. Необхідність модернізації системи стратегічного державного регулювання інноваційного розвитку транспортної інфраструктури зумовлено браком інноваційних змін в транспортному комплексі, що $є$ результатом недієвості та непослідовності державної політики у сфері підтримки та стимулювання інноваційних процесів в галузі.

Тому актуальним питанням в умовах ринкової економіки, що характеризується зростаючою невизначеністю розвитку зовнішнього середовища, неповнотою і асиметрією інформації, періодами підйому і спаду економічного розвитку, $\epsilon$ формування системи державного стратегічного управління інноваційним розвитком транспортної інфраструктури.

Аналіз останніх досліджень i публікацій. Теорія державного стратегічного управління має гарну методологічну основу для розвитку, яка включає теорії державного регулювання економіки, теорії стратегічного прогнозування та стратегічного планування. Поняття «стратегічне управління» було введено в теорію і практику управління на рубежі 60-70-х pp. ХХ ст. У числі основних розробників системи стратегічного управління і планування можна виділити таких вчених, як Д. Аакер, Р. Акофф, І. Ансофф, Х. Віссема, Р. Грант, В. Кінг, Д. Кліланд, М. Портер, М. Мескон, М. Альберт, Ф. Хедоурі, Г. Мінцберг, Д. Тіс, Г. Пізано і Е. Шуєн, А. Стрікленд, А. Томпсон, Г. Хамел і К. Прахалад та ін. [1-4]. Названі вчені розглядають широке коло питань, пов'язаних з розробкою і реалізацією стратегічного управління в сучасних умовах. Ними закладено основні теоретичні концепції стратегічного управління, а також визначено його ключові складові. Проблеми стратегічного управління в вітчизняній транспортній сфері вирішуються в роботах таких вчених, як В. Дикань, О. Дикань, М. Корінь, О. Криворучко, В. Овчиннікова, І. Токмакова, Л. Українська, В. Шинкаренко, В. Яновська та інших [5-12].

Слід констатувати, що відсутність стратегічного управління на 
державному рівні проявляється, перш за все, в наступних двох аспектах:

1) держава здійснює свою діяльність виходячи 3 того, що зовнішнє оточення або не буде взагалі змінюватися, або в ньому не буде відбуватися якісних змін;

2) при не стратегічному управлінні вироблення програми дій починається 3 аналізу внутрішніх можливостей, ресурсів держави, а основні тенденції розвитку зовнішнього середовища виявляються поза увагою.

Аналіз праць вчених $[1,2,5,13]$ показує, що державне стратегічне управління - це науково обгрунтований вплив керівників держави, апарату державного управління, політичних і громадських організацій на соціальноекономічне середовище держави, що забезпечує довгострокове, стійке зростання економіки i якості життя, забезпечення безпеки особистості i держави, попередження надзвичайних ситуацій.

Невирішені складові загальної проблеми. Враховуючи наукове та практичне значення праць вищезазначених авторів, слід підкреслити, що існує потреба в удосконаленні теоретичних основ стратегічного державного управління інноваційним розвитком транспортної інфраструктури у частині класифікації інноваційних стратегій.

Формулювання цілей статті. Метою статті $є$ визначення підходів, принципів i етапів реалізації державного стратегічного управління інноваційним розвитком транспортної інфраструктури; розроблення типізації інноваційних стратегій на основі встановлення ознак і сутності інноваційної стратегії як ключового елемента в системі стратегічного управління.

Виклад основного матеріалу дослідження. Відповідно до вищеподаного визначення державне стратегічне управління інноваційним розвитком транспортної інфраструктури - це науково обгрунтований вплив керівників держави, апарату державного управління, політичних і громадських організацій на соціально-економічне середовище транспортного комплексу та інноваційної системи країни, що забезпечує якість і конкурентоспроможність транспортних послуг та сталий розвиток транспортного сектора економіки.

Методологію державного стратегічного управління можна визначити як сукупність теоретичних принципів і методів, що використовуються в процесі державного стратегічного управління. У широкому сенсі слова методологію державного стратегічного управління можна визначити як єдність системи методів державного стратегічного управління; специфічних методологічних принципів; етапів процесу державного стратегічного управління; системи показників, що використовуються в процесі державного управління.

Основні концептуальні підходи теорії управління, що формують теоретико-методологічні засади стратегічного державного управління такі [14]:

1. Системний підхід детально досліджує властивості та елементи складно організованих систем для цілеспрямованого впливу.

2. Кібернетичний підхід передбачає розгляд взаємодії керуючої (суб'єкта управління) i керованої (об'єкт управління) підсистем. $€$ основоположним при структуризації системи управління будь-якого типу та 
ієрархічного рівня.

3. Базою функціонального підходу в стратегічному управлінні служить дослідження операцій, на основі яких проєктуються, описуються, аналізуються і оптимізуються управлінські функції. В рамках даного підходу отримала свій розвиток лінія стратегічного планування, яке визначає зміст стратегічного управління. Функціональний підхід передбачає розгляд сукупності видів діяльності 3 управління, їх змісту, а також результатів цієї діяльності в залежності від факторів внутрішнього і зовнішнього середовища. Необхідний для змістовного розуміння того, як діє система, який механізм цілепокладання $\mathrm{i}$ забезпечення цілей.

4. Логікою програмно-цільового підходу виступає парадигма «програма - мета - результат». У цьому підході рух від мети до результату описується за допомогою програмних засобів, таким чином, програмується (алгоритмується, операціоналізується) сам процес руху від моменту постановки мети до отримання результату. В рамках даного підходу зародилася система управління за результатами.

5. Проєктний підхід базується на понятті «проєкт», який виступає не тільки як об'єкт управління, що володіє деякими специфічними рисами, але і як загальна характеристика суті управління проєктом, як його нова властивість.

6. Підхід на основі теорії прийняття рішень розглядається з точки зору процесу їх підготовки та реалізації на основі типологізації, що виводить дослідників на визначення стратегічних рішень. В основі теорії прийняття рішень лежить акторний погляд на управлінську діяльність, процес управління розглядається 3 точки зору підготовки та прийняття рішень. Серед управлінських рішень дослідники виділяють і такий його тип, як стратегічний, що розглядається як засіб раціоналізації проблем стратегічного управління, перш за все цілепокладання. Мінус даного підходу в тому, що результати залежать від якості роботи, особистої компетенції та бачення управлінця, тому при зміні посадової особи позитивна тенденція в реалізації стратегії може змінитися.

7. Маркетинговий підхід пов'язаний 3 постійним i систематичним аналізом потреб ринку, з необхідністю управляти по-новому з орієнтацією на оточення, зокрема на запити споживачів, що виводить на розробку ефективних товарів, призначених для конкретних груп покупців, які мають особливі властивості, що відрізняють їх від товарів-конкурентів i таким чином створюють виробнику стійку конкурентну перевагу.

8. Ресурсний підхід розглядає ресурси як джерела i одночасно обмеження на будь-яку діяльність. Проблематика підходу виявляється при розмежуванні ресурсів на тактичні і стратегічні, при цьому стратегічні ресурси обов'язково є наявними, тобто існуючими в даний час.

9. Процесний підхід розглядає всі функції управління в єдності i постійних взаємозв'язках, які виконуються в певній послідовності. Управління розглядається як процес безперервних взаємопов'язаних дій (функцій), кожна 3 яких, в свою чергу, також складається з декількох взаємопов'язаних дій. Вони 
об'єднані зв'язуючими процесами комунікацій і прийняття рішень. При цьому керівництво розглядається як самостійна діяльність, яка впливає безпосередньо на підлеглих таким чином, щоб вони діяли в напрямі досягнення поставлених цілей.

10. Ціннісно-орієнтований підхід до управління, відповідно до якого в якості інтегрального оціночного показника ефективності перетворень приймається гарантоване стабільне зростання вартості бізнесу. Даний підхід забезпечує кількісну оцінку результатів підприємницької діяльності в грошовій формі, що $\epsilon$ апріорною методологічною вимогою для будь-якого господарюючого суб'єкта, що функціонує в економічній системі, заснованій на еквівалентному товарно-грошовому обміні.

В цілому у складі методології державного стратегічного управління виділяють такі напрямки $[14,15]$ :

- залучення до процесу стратегічного планування відповідальних виконавців;

- розвиток через узгодження інтересів і навчання, при якому різноспрямовані інтереси бізнесу, влади і суспільства узгоджуються для максимізації загальної вигоди в довгостроковій перспективі;

- оцінку ближнього і далекого майбутнього;

- концепцію стратегічних ініціатив розвитку, яка забезпечує єдність у підходах до планування та взаємозв'язок проєктів стратегічного розвитку;

- цілепокладання як базу стратегування.

Дослідження теоретико-методичних аспектів стратегічного управління інноваційним розвитком транспортної інфраструктури не буде повноцінним без розгляду принципів. Відповідно до традиційних визначень принципи стратегічного управління являють собою початкові керівні ідеї та критерії, покладені в основу реалізації досягнення цілей і завдань розвитку.

Як показують дослідження [16] стратегічне управління інноваційним розвитком транспортної інфраструктури має базуватися на таких принципах.

Принцип єдності та цілісності системи державного стратегічного управління означає єдність принципів організації та функціонування системи даної системи, єдність порядку здійснення процесу державного стратегічного управління та формування звітності 3 реалізації документів стратегічного управління.

Принцип внутрішньої збалансованості системи державного стратегічного управління означає узгодженість основних елементів даної системи між собою за цілями, завданнями і заходами.

Принцип результативності та ефективності функціонування системи державного стратегічного управління означає, що вибір способів і методів досягнення цілей повинен грунтуватися на необхідності досягнення заданих результатів з найменшими витратами ресурсів.

Принцип самостійності вибору шляхів вирішення завдань означає, що учасники процесу державного стратегічного управління в межах своєї компетенції самостійні у виборі шляхів і методів досягнення цілей і вирішення 
завдань.

Принцип відповідальності учасників процесу державного стратегічного управління означає, що учасники процесу несуть відповідальність за ефективність вирішення завдань та здійснення заходів щодо досягнення цілей у межах своєї компетенції відповідно до законодавства.

Принцип прозорості (відкритості) процесу державного стратегічного управління означає, що документи, що розробляються в рамках системи державного стратегічного управління, за винятком положень, що містять інформацію, що відноситься до державної таємниці, підлягають офіційному опублікуванню, проєкти документів $є$ предметом громадського обговорення.

Принцип достовірності і реалістичності означає обгрунтовану можливість досягнення цілей, встановлених в рамках системи державного стратегічного управління, а також обгрунтованість показників, що використовуються в процесі державного стратегічного планування.

Принцип наступності і безперервності означає, що розробка і реалізація державних стратегічних документів здійснюються послідовно з урахуванням результатів реалізації раніше прийнятих державних стратегічних документів.

Принцип фінансової забезпеченості означає, що при розробці та затвердженні документів державного стратегічного управління, які передбачають здійснення видатків, мають бути визначені джерела їх фінансування 3 урахуванням основних показників бюджетної системи на середньострокову та довгострокову перспективу.

Принцип максимального використання ринкових механізмів активізації інноваційної діяльності вказують на необхідність впровадження економічних методів і важелів державного регулювання з урахуванням потреб і вимог ринку.

Принцип використання власного науково-технічного потенціалу держави пов'язаний 3 впровадженням організаційних трансформацій у структурі науково-технічної складової, метою яких $є$ підвищення конкурентоспроможності національної інноваційної системи.

Наразі перевагами використання механізму державного стратегічного управління інноваційного розвитку транспортної інфраструктури є:

- застосування нових методів та інструментів роботи 3 майбутнім (методи форсайту, «картування» руху — розробка «карт майбутнього» та ін.);

- модернізація існуючої системи стратегічного планування;

- систематизація окремих засобів управління розвитком (програмних, проєктних, планових та ін.) з різними рівнями і часовими горизонтами;

- системне опрацювання i вирішення всього спектру проблем, пов'язаних з реалізацією стратегій;

- формування механізмів стратегічного управління на основі партнерства (державних i підприємницьких структур, некомерційних організацій, населення) та організації процесів комунікації та інституціоналізації діяльності стратегічних суб'єктів для вирішення проблем. Основними елементами ефективної системи стратегічного державного управління повинні стати: 
- комплекс стратегічних цілей;

- механізм координації роботи відомств по досягненню поставлених стратегічних цілей (вирішується проблема фрагментарності управлінського процесу);

- середньострокові завдання - набір найбільш важливих середньострокових зобов'язань, які визначають внесок кожного відомства в процес досягнення стратегічних цілей;

- інструмент підзвітності керівників як відомств, так i окремих департаментів (інструмент моделі класичної бюрократії);

- особиста відповідальність керівників відомств і департаментів за виконання середньострокових завдань.

Етапи і складові стратегічного управління інноваційним розвитком подано на рис. 1.

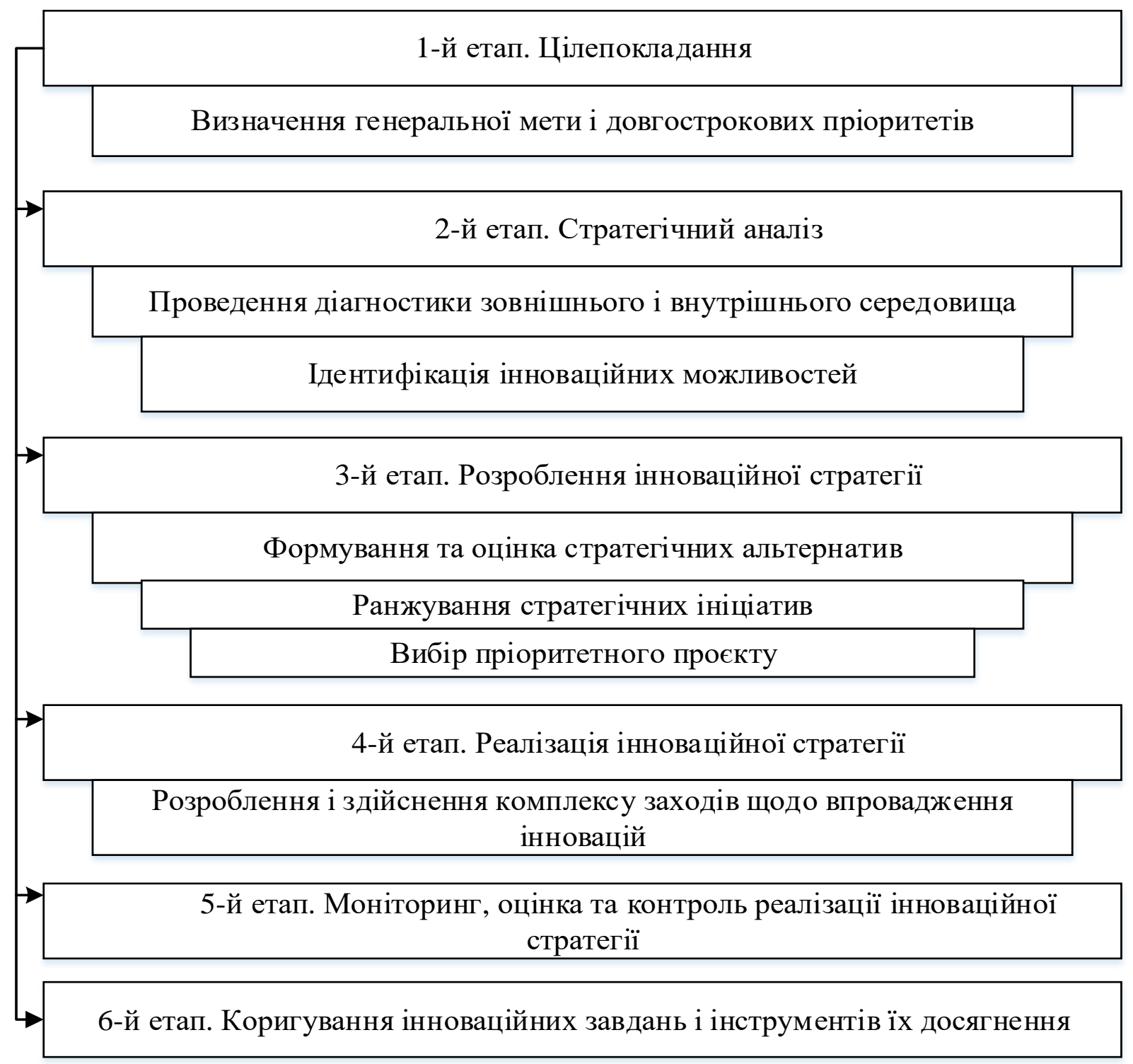

Рис. 1. Етапи і складові стратегічного управління інноваційним розвитком Джерело: складено авторами за даними джерел [3-5;17] 
У державному стратегічному управлінні центральне місце займає процес розроблення і реалізації стратегії.

Існує велика кількість трактувань поняття інноваційної стратегії, і це свідчить про те, що в наукових колах немає єдиної думки і підходу до цього питання. Ї̈̈ основні характеристики подано на рис. 2.

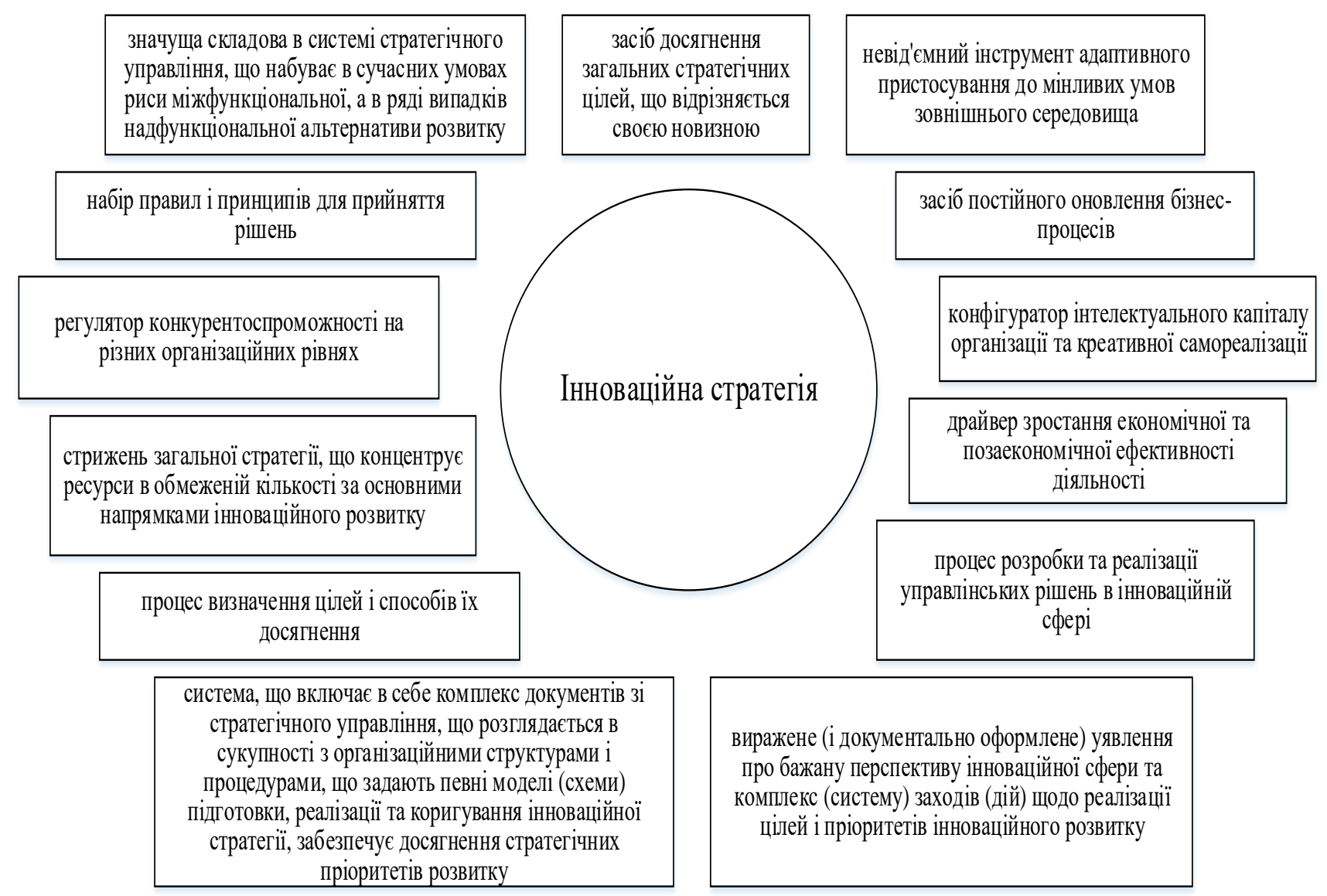

\section{Рис. 2. Змістовні аспекти інноваційної стратегії}

\section{Джерело: складено авторами за даними джерел [18-20]}

Кожний із зазначених на рис. 2 підходів характеризує визначений аспект інноваційної стратегії економічної системи, підкреслюючи найбільш істотні ії риси й особливості. Поряд 3 цим розглянуті підходи не суперечать один одному, а відображають різні сторони стратегії, в зв'язку з чим, застосування всіх перерахованих вище підходів дозволяє отримати найбільш повне розуміння сутності і змісту інноваційної стратегія як цілеспрямованої діяльності щодо визначення найважливіших напрямів, вибору пріоритетів перспектив розвитку і вироблення необхідного для їх досягнення комплексу заходів. Це набір правил і норм, що визначають процедуру зміни системи відбору і реалізації нововведень, як в технології, так і в управлінні технологією.

Узагальнюючи вищезазначене, можна сказати, що інноваційна стратегія розвитку транспортної інфраструктури повинна:

- встановлювати пріоритети розвитку інноваційної діяльності на транспорті;

- визначати план конкретних дій щодо державного управління 
розвитком інноваційної діяльності в транспортній сфері;

- враховувати інноваційну стратегію держави;

- узгоджуватися зі стратегіями розвитку галузей;

- узгоджуватися 3 інноваційними транспортними стратегіями зарубіжних країн-партнерів;

- узгоджуватися 3 інноваційними стратегіями суб'єктів інноваційної системи країни, які здійснюють інноваційну діяльність;

- забезпечити вироблення єдиної позиції і загального розуміння всіма суб'єктами транспортної інфраструктури змін, що відбуваються в інноваційній сфері;

- визначати ступінь і форму участі державних і регіональних органів влади у розвитку інноваційної сфери транспорту;

- забезпечити консолідацію зусиль і потенціалу всіх суб'єктів транспорту та їх партнерів на реалізації обраних пріоритетів розвитку інноваційної діяльності.

Розробляючи хід формування інноваційної стратегії, крім пріоритетних напрямків розвитку інноваційної діяльності потрібно встановити склад, роль $\mathrm{i}$ місце великої кількості суб'єктів стратегічно орієнтованої інноваційної системи, а також обгрунтувати реалізацію моделі формування інноваційного середовища для досягнення пріоритетних цілей інноваційного розвитку стратегічно орієнтованої економіки. Таким чином, при формуванні інноваційних стратегій 3 науково-теоретичної точки зору необхідно спиратися на їх основні класифікаційні ознаки.

У науковій літературі на сьогоднішній день накопичено певний досвід типізації інноваційних стратегій за різними ознаками (за типами інновацій, характерною особливістю інновацій, сутністю інновацій, їх рівнями тощо) (табл. 1).

Розглянуті варіанти типології вказують на превалювання поведінкового підходу до типізації, а також дозволяють зробити висновок, що поширеним $\epsilon$ використання різних визначень для характеристики одного і того ж виду стратегії, при цьому зберігається єдина точку зору на їі зміст і умови вибору. Це відноситься до назви класів інноваційних стратегій, коли нарівні з поняттям «оборонної» стратегії використовується поняття «адаптаційна», «пасивна», а синонімами поняття «наступальна» служать поняття «активна», «творча» та ін.

В поведінковому контексті слід враховувати практику індустріальних країн, які домоглися успіхів у реалізації нововведень, підвищенні обсягів виробництва та експорту наукомісткої продукції, яка вказує на існування наступних інноваційних стратегій [33].

1. Стратегія «нарощування», що грунтується на використанні власного науково-технічного потенціалу та залученні зарубіжного досвіду. При раціональному об'єднанні результатів фундаментальної і прикладної науки поступово нарощується виробництво конкурентоспроможної продукції, відпрацьовуються високі технології, які реалізуються у виробництві і в соціальній сфері. 
Класифікація інноваційних стратегій

\begin{tabular}{|c|c|}
\hline \\
\hline Вид стратегій & Сутність \\
\hline 1 & 2 \\
\hline \multicolumn{2}{|r|}{ Залежно від поведінки підприємства у ринковому середовищі } \\
\hline $\begin{array}{c}\text { Наступальна } \\
\text { (агресивна) }\end{array}$ & $\begin{array}{c}\text { Забезпечують реалізацію загальної стратегії інтенсивного росту і націлені на збільшення присутності в найбільш } \\
\text { перспективних секторах ринку за рахунок витіснення з цих секторів наявних конкурентів. У більшості випадків, } \\
\text { реалізуються за рахунок великомасштабних інноваційних розробок, що грунтуються на стратегічно значимих НДДКР } \\
\text { і призводять до встановлення технологічного і (або) продуктового лідерства підприємства }\end{array}$ \\
\hline $\begin{array}{l}\text { Оборонна } \\
\text { (захисна) }\end{array}$ & $\begin{array}{l}\text { Збереження позиції є використанням результатів спостереження за діями підприємств-лідерів на ринку, що дозволяє } \\
\text { за короткий час відтворити досягнення цих фірм та вийти на ринок слідом за ними без претензій на провідні позиції }\end{array}$ \\
\hline Імітаційна & $\begin{array}{c}\text { Припускає швидке освоєння підприємством галузевих новинок в продуктовій або технологічній областях без } \\
\text { проведення власних значних НДДКР за рахунок копіювання новаторських ідей галузевих лідерів }\end{array}$ \\
\hline Традиційна & $\begin{array}{c}\text { Полягає у підвищенні якості існуючого товару на існуючій технологічній базі. Наслідок цього варіанту стратегічного } \\
\text { розвитку може проявитись у послідовному відставанні фірми спочатку в техніко-технологічному, а потім і в } \\
\text { економічному відношенні }\end{array}$ \\
\hline Стратегія «ніші» & $\begin{array}{c}\text { Складається в спеціалізації на виробництві у новій ніші або оновленій продукції з унікальними характеристиками. } \\
\text { Стратегія спирається на поділ продукції та фокусування на вузькому ринковому сегменті. Часто компанії, що } \\
\text { застосовують цю стратегію, називають фірмами-патієнтам }\end{array}$ \\
\hline \multicolumn{2}{|r|}{ Залежно від типу конкурентної стратегічної інновачійної поведінки } \\
\hline Віолентна & $\begin{array}{c}\text { Вихід на масовий ринок зі своєю або придбаною новою продукцією, випереджання конкурентів за рахунок серійності } \\
\text { виробництва і ефекту масштабу }\end{array}$ \\
\hline Експлерентна & Вихід на ринок з новим (радикально інноваційним) продуктом або захоплення частини ринку \\
\hline Комутантна & $\begin{array}{c}\text { Пристосування до умов попиту місцевого ринку; захоплення сегментів, які з тих або інших причин не зайняті } \\
\text { віолентами і патієнтами, освоєння нових видів послуг після появи нових продуктів і нових технологій, імітації } \\
\text { новинок і просунення їх до самих широких верств населення }\end{array}$ \\
\hline Патієнтна & $\begin{array}{c}\text { Пристосування до вузьких сегментів широкого ринку шляхом спеціалізованого випуску нової або модернізованої } \\
\text { продукції з унікальними властивостями }\end{array}$ \\
\hline \multicolumn{2}{|r|}{ Залежно від типу інноваиії і рівня розробки існуючої технології } \\
\hline Конкурентна & Упевненість в успішності інновації \\
\hline Співробітництва & Поділу функцій з дочірніми підприємствами \\
\hline $\begin{array}{l}\text { Опори на власні } \\
\text { сили }\end{array}$ & Достатності власного потенціалу \\
\hline
\end{tabular}




\begin{tabular}{|c|c|}
\hline 1 & 2 \\
\hline \multicolumn{2}{|r|}{ Залежно від ступеня новизни товару і ринку (за І. Ансофом) } \\
\hline $\begin{array}{l}\text { Глибокого } \\
\text { проникнення на } \\
\text { ринок }\end{array}$ & $\begin{array}{c}\text { Стратегії проникнення і посилення позицій на ринку - стимулювання покупок традиційними покупцями, збільшення } \\
\text { частки ринку, залучення покупців від конкурентів, залучення нових споживачів, пошук нових можливостей } \\
\text { користування }\end{array}$ \\
\hline Розвитку ринку & Вихід на нові сегменти, нові територіальні ринки, нові збутові мережі \\
\hline Розвитку товару & $\begin{array}{c}\text { Впровадження інноваційних товарів, нових марок; модифікація асортименту, вдосконалення параметрів продукції, } \\
\text { розвиток інструментальних та емоційних характеристик тощо }\end{array}$ \\
\hline Диверсифікації & $\begin{array}{c}\text { Реалізується тоді, коли підприємства не можуть далі розвиватися на конкретному ринку з певним товаром у межах } \\
\text { певної галузі. Освоєння абсолютно нових видів діяльності }\end{array}$ \\
\hline \multicolumn{2}{|r|}{ Залежно від стадії життєвого циклу інновачї } \\
\hline Відновлення & $\begin{array}{c}\text { Реалізують тоді, коли потребує перегрупування сил після тривалого зростання або у зв'язку з необхідністю } \\
\text { підвищення ефективності, коли спостерігаються спади та кардинальні зміни в економіці }\end{array}$ \\
\hline Проникнення & $\begin{array}{c}\text { Стратегії проникнення і посилення позицій на ринку (стимулювання покупок традиційними покупцями, збільшення } \\
\text { частки ринку, залучення покупців від конкурентів, залучення нових споживачів, пошук нових можливостей) }\end{array}$ \\
\hline Наступу & $\begin{array}{c}\text { Застосовують у галузях зі стабільною технологією. Цілі розвитку визначаються «від досягнутого» і коригуються на } \\
\text { умови, що змінюються }\end{array}$ \\
\hline Захисту & $\begin{array}{c}\text { Передбачає визначення цілей нижчого рівня, ніж досягнутий у минулому, і використовується тоді, коли показники } \\
\text { діяльності підприємства набувають стійкої тенденції до погіршення }\end{array}$ \\
\hline Виходу з ринку & Ліквідація, «збирання урожаю», скорочення виробництва, скорочення витрат \\
\hline \multicolumn{2}{|r|}{ Відповідно до типів інновачій, визначених Й. Шумпетером } \\
\hline Нового товару & Стратегія виведення на ринок нового товару \\
\hline $\begin{array}{l}\text { Нового методу } \\
\text { виробництва }\end{array}$ & Створення нового методу виробництва \\
\hline Нового ринку & Стратегія виходу на новий ринок \\
\hline Нових ресурсів & Стратегія застосування нового джерела ресурсів виробництва \\
\hline Нової організації & Стратегія створення нової організації \\
\hline \multicolumn{2}{|r|}{ Залежно від ступеня новизни товару, ринку і технологій } \\
\hline Архітектурна & $\begin{array}{c}\text { Реалізується в разі розробки новітніх технологій, які використовуються виробником для створення нових } \\
\text { інноваційних товарів і, відповідно, нових ринків. Орієнтується на здійснення досліджень за кількома різноманітними } \\
\text { науковими напрямами, результати яких можуть мати багатоцільове застосування та розв'язувати різні проблеми } \\
\text { споживачів. Кінцевим результатом науково-технологічної діяльності є створення так званої архітектурної }\end{array}$ \\
\hline
\end{tabular}


Продовження табл. 1

\begin{tabular}{|c|c|}
\hline 1 & 2 \\
\hline & $\begin{array}{l}\text { інновації, технологічні переваги якої надають розробнику можливість формувати структуру нового ринку, } \\
\text { встановлювати власні правила щодо товарної політики, стратегії ціноутворення, маркетингових заходів }\end{array}$ \\
\hline $\begin{array}{l}\text { Зовнішніх } \\
\text { модифікуючи } \\
\text { інновацій }\end{array}$ & $\begin{array}{c}\text { Націлює на здійснення науково-конструкторських робіт, які дають можливість удосконалювати кінцевий продукт, що } \\
\text { вже є на ринку. Однак впровадження різноманітних модифікуючи інновацій сприяє створенню ринкових ніш, } \\
\text { споживачі яких надають перевагу запропонованому продукту завдяки використанню новітньої технології та } \\
\text { унікальним властивостям }\end{array}$ \\
\hline $\begin{array}{l}\text { Заглиблюючих } \\
\text { інновацій }\end{array}$ & $\begin{array}{c}\text { Пов'язана з розробленням новітньої технології, яка дає можливість створювати нові продукти, що приваблюють } \\
\text { споживачів низкою суттєвих технологічних переваг. Новий товар задовольняє існуючі потреби споживачів на якісно } \\
\text { новому рівні. Впровадження інноваційної технології підвищує універсальність продукту, зручність його використання, } \\
\text { безпеку. Виробник глибше проникає на сформований ринок і займає лідируючі позиції }\end{array}$ \\
\hline $\begin{array}{l}\text { Внутрішніх } \\
\text { модифікуючих } \\
\text { інновацій }\end{array}$ & $\begin{array}{c}\text { Новітні технологічні розробки формують широке коло можливостей щодо створення різноманітних модифікацій } \\
\text { товару, який використовують споживачі. Інноваційна діяльність у цьому напрямі ілюструє активне застосування } \\
\text { приростаючих інновацій, що, у свою чергу, сприяє розширенню товарного асортименту, продовженню життєвого } \\
\text { циклу продукції, більш якісному задоволенню існуючих ринкових потреб, зміцненню позицій підприємства на } \\
\text { знайомому ринку та підвищенню його конкурентоспроможності }\end{array}$ \\
\hline \multicolumn{2}{|r|}{ Залежно від організачійної поведінки } \\
\hline $\begin{array}{c}\text { Стратегія } \\
\text { передконкурентної } \\
\text { консолідації }\end{array}$ & $\begin{array}{c}\text { Використовується на ранніх стадіях НДДКР. Представляється двома субстратегіями - пільгового ліцензування } \\
\text { (надання учасникам спільних НДДКР ліцензій за пільговими цінами, в цьому випадку патентом володіє вся система в } \\
\text { цілому) і пропорційного доступу (передбачає співвимір розміру пільг і внеску підприємства в НДДКР) }\end{array}$ \\
\hline Централізації & $\begin{array}{c}\text { Проведення НДДКР здійснюється науково-технічною організацією групи, напрям діяльності якої визначається } \\
\text { органами управління групових виробничо-економічних систем у цілому }\end{array}$ \\
\hline Субцентралізації & НДДКР в групі поділені за окремими галузями, кожна з яких реалізує свою стратегію науково-технічного розвитку \\
\hline Децентралізації & $\begin{array}{c}\text { Організації групи самостійно формують стратегії розвитку, організовують процеси досліджень і розробок силами } \\
\text { власних підрозділів або замовляють їх на стороні }\end{array}$ \\
\hline \multicolumn{2}{|r|}{ За рівнем новизни впроваджуваної інновачії } \\
\hline $\begin{array}{c}\text { Активні } \\
\text { (наступальні, } \\
\text { революційні) }\end{array}$ & $\begin{array}{c}\text { Стратегія першого виходу на ринок з нововведенням, яке до цього часу не випускалося. Неперервний розвиток і } \\
\text { вдосконалення виготовлюваних виробів і застосовуваних технологій }\end{array}$ \\
\hline $\begin{array}{l}\text { Пасивні } \\
\text { (маркетингові, } \\
\text { імітаційні) }\end{array}$ & $\begin{array}{c}\text { Стратегія оновлення виготовлюваної продукції, яке не вимагає серйозних змін у засобах виробництва чи } \\
\text { застосовуваних технологіях, не потребує додаткових витрат розумової праці та не приводить до докорінних змін у } \\
\text { техніко-технологічних характеристиках виробу, а лише підтримує досягнутий рівень технології }\end{array}$ \\
\hline
\end{tabular}


Продовження табл. 1

\begin{tabular}{|c|c|}
\hline 1 & 2 \\
\hline \multicolumn{2}{|r|}{ Залежно від стадії застосування стратегії } \\
\hline $\begin{array}{l}\text { Проведення } \\
\text { НДДКР }\end{array}$ & Пов'язана з проведенням досліджень і розробок \\
\hline $\begin{array}{c}\text { Впровадження та } \\
\text { адаптації } \\
\text { нововведень }\end{array}$ & Відноситься до системи оновлення виробництва, виведення продуктів на ринки, використання технологічних переваг \\
\hline \multicolumn{2}{|r|}{ За типом стратегічної технологічної поведінки } \\
\hline Власних НДДКР & Проведення НДДКР власними силами шляхом використання науково- виробничої бази, яка є в наявності в організації \\
\hline $\begin{array}{l}\text { Збереження } \\
\text { існуючого техніко- } \\
\text { технологічного } \\
\text { рівня }\end{array}$ & Може бути як осмисленою стратегією так і примусовою через нестачу фінансових коштів \\
\hline Ліцензійна & Здійснення інноваційної діяльності на основі придбаних ліцензій, авторських прав, ноу-хау і розробок \\
\hline $\begin{array}{l}\text { Інноваційного } \\
\text { аутсорингу }\end{array}$ & $\begin{array}{c}\text { Охоплює тільки один або декілька етапів інноваційного процесу, здійснення тільки тих видів діяльності, які необхідні } \\
\text { для реалізації визначеного інноваційного процесу, а результати інших видів діяльності, які складають окремі етапи } \\
\text { процесу розробки і здійснення даної інновації, купляються у інших організацій } \\
\end{array}$ \\
\hline $\begin{array}{l}\text { Фінансування } \\
\text { НДДКР }\end{array}$ & $\begin{array}{c}\text { Виходячи із стратегічних задач спрямовано фінансується проведення НДДКР в науково-дослідних закладах в } \\
\text { необхідних напрямах з метою отримання принципово нового продукту на ринку }\end{array}$ \\
\hline \multicolumn{2}{|r|}{ Тип стратегічної поведінки } \\
\hline Проактивна & $\begin{array}{c}\text { Обумовлює значні витрати на інноваційні дослідження і в разі успіху забезпечується комерційний ефект та } \\
\text { формування позиції «лідера ринку нових технологій» }\end{array}$ \\
\hline $\begin{array}{c}\text { Активна } \\
\text { (наступальна) }\end{array}$ & $\begin{array}{c}\text { Включає в себе захист існуючих технологій і ринків, але з готовністю швидко реагувати на динамічні зміни } \\
\text { зовнішнього середовища }\end{array}$ \\
\hline Реактивна & $\begin{array}{c}\text { Використовується послідовниками і мають на ринку очікувальну позицію, оскільки забезпечують низький ризик } \\
\text { реалізації інноваційної діяльності }\end{array}$ \\
\hline Пасивна (захисна) & Чекають, поки їх клієнти вимагатимуть зміни у своїх продуктах або послугах \\
\hline
\end{tabular}

Джерело: складено авторами за даними джерел [21-32] 
2. Стратегія «запозичення». Суть iï полягає в тому, щоб, спираючись на дешеву робочу силу і використовуючи частину науково-технічного потенціалу власної країни, освоювати випуск наукомісткої продукції, що вироблялася раніше в розвинених індустріальних країнах. Далі нарощується виробництво продукції з відродженням науково-технічного і промислового потенціалу, задіяння якого дозволяє проводити роботи по всьому інноваційному циклу (від створення до реалізації продукту).

3. Стратегія «перенесення», що полягає у використанні в економіці країни зарубіжного науково-технічного потенціалу за допомогою закупівлі ліцензій на високоефективні технології для освоєння виробництва продукції нових поколінь, що користується попитом за кордоном. В подальшому в країні створюється і множиться власний науково-технічний і промисловий потенціал, забезпечується відтворення всього циклу (від фундаментальних досліджень і розробок до виробництва і реалізації конкурентоспроможної продукції на внутрішніх ринках і за кордоном).

Однак даний підхід, як і більшість 3 вишевизначених в табл. 1 не дозволяють організувати ідеальний тип інноваційної стратегії, так як комплексно не орієнтовані на забезпечення якості інноваційного процесу, що включає комбінацію декількох факторів:

- спрямованість інноваційного процесу;

- ступінь унікальності використовуваних інновацій;

- ступінь вираженості інноваційної орієнтації управління.

Беручи до уваги вищесказане і врахувавши комплекс пріоритетних критеріїв (направленість результату, тип інновацій, характер дій) розроблено класифікацію стратегій інноваційного розвитку транспортної інфраструктури (табл. 2).

Таблиия 2

Типи інноваційних стратегій розвитку транспортної інфраструктури

\begin{tabular}{|c|c|c|c|c|c|}
\hline $\begin{array}{c}\text { Направленість } \\
\text { результату }\end{array}$ & Деградація & Дестабілізація & Стабілізація & Збалансованість & Прогрес \\
\hline Тип інновацій & Мнимі & $\begin{array}{c}\text { Псевдо- } \\
\text { інновації }\end{array}$ & Покращуючи & Комбінаторні & $\begin{array}{c}\text { Радикальні } \\
\text { (базові i } \\
\text { проривні) }\end{array}$ \\
\hline Характер дій & Імітаційний & Пасивний & Реактивний & Активний & Проактивний \\
\hline $\begin{array}{c}\text { Типи } \\
\text { інноваційних } \\
\text { стратегій }\end{array}$ & \multicolumn{2}{|c|}{ Деструктивні } & \multicolumn{3}{|c|}{ Конструктивні } \\
\hline $\begin{array}{c}\text { Підтипи } \\
\text { інноваційних } \\
\text { стратегій }\end{array}$ & $\begin{array}{c}\text { Псевдоінно- } \\
\text { ваційні }\end{array}$ & $\begin{array}{c}\text { Квазіінно- } \\
\text { ваційні }\end{array}$ & Адаптивні & Оптимізуючі & Прогресивні \\
\hline
\end{tabular}

Джерело: розроблено авторами

Результативність інноваційної діяльності транспортного комплексу оцінена за шкалою «негативних-позитивних» наслідків для розвитку галузі, серед яких деградація, дестабілізації, стабілізація, збалансованість, прогрес. 
Тип інновацій визначено за їх інноваційним потенціалом:

1. Радикальні інновації або фундаментальні, глобальні, базові нововведення - це продукти, процеси або послуги, що володіють або раніше невідомими властивостями, або відомими, але значно поліпшеними характеристиками продуктивності та/або ціною. Радикальні інновації створюють такі значні зміни в процесах, продукти та послуги, що призводять до трансформації існуючих ринків і галузей або створюють нові ринки і галузі.

2. Комбінаторні інновації грунтуються на використанні поєднань різних наявних елементів, які в такому варіанті ще не використовувались. Вони $є$ не будь-яким поєднанням, а саме конструктивним, тобто таким, за якого 3'являються нові системні властивості і які породжують новий ефект. Комбінаторні інновації забезпечують утримання переваги над конкурентами за рахунок створення нових видів продукту.

3. Поліпшуючі інновації представляють собою зміни, багато в чому зумовлені існуючими знаннями, продуктами та технологіями, що дають істотне удосконалення базисних продуктів i процесів. До них відносяться вдосконалення, інтенсифікація існуючих технологічних процесів, які здійснюються за рахунок реконструкції і технічного переозброєння.

4. Псевдоінновації (квазіінновації) - це зовнішні зміни продуктів або процесів, що не приводять до зміни їх споживчих характеристик а також спрямовані на часткове поліпшення застарілих поколінь техніки і технологій.

5. Мнимі інновації - це ідеї, які фактично не планується або реально не можливо реалізувати.

Характер дій вказує на бажаний рівень інноваційної активності транспортної галузі, він може бути імітаційний, пасивний, реактивний, активний і проактивний.

В залежності від поєднання наведених вище критеріїв виділено конструктивні і деструктивні стратегії. В межах деструктивних стратегій запропоновано виділяти псевдо- і квазіінноваційні, а в межах конструктивних адаптивні, оптимізаційні та прогресивні.

Конструктивні стратегії характеризуються таким чином. Адаптивні стратегії орієнтовані на процес модернізації транспортної інфраструктури i передбачають переоснащення транспортного комплексу відповідно до сучасних вимог до техніки і технологій. В основі процесу модернізації має знаходитися стратегія розвитку, заснована на впровадженні різних нововведень адаптивного характеру.

На даному етапі транспортна інфраструктура буде перебувати на стадії «наздоганяючого розвитку», яка в перспективі повинна сприяти переходу до стадії інноваційного розвитку. Основними завданнями даної стратегії є: будівництво i реконструкція транспортних магістралей, формування нових комунікаційних маршрутів, заміна рухомого складу i транспортної інфраструктури, що виробили свій ресурс.

Оптимізаційні стратегії забезпечують перехід від «наздоганяючого розвитку» транспортної інфраструктури до інноваційного, що передбачає 
вдосконалення транспортних засобів і технологічних процесів, впровадження нової техніки та високоефективних технологій, підвищення конкурентоспроможності транспортних послуг. Реалізація таких стратегій потребує поширення інтеграційних процесів у сфері науки, держави і бізнесу для організації НДДКР і створення ресурсної бази для впровадження інновацій.

Прогресивні стратегії націлені на випереджаючий розвиток транспортної інфраструктури, що передбачає розроблення фундаментальних, глобальних i базових нововведень і відповідно реалізацію проектів розбудову інноваційної транспортної інфраструктури на основі використання вітчизняних розробок в сфері нових матеріалів і технологій в транспортному будівництві, створення нових видів транспорту, які можуть бути конкурентоспроможними не тільки в регіонах, країні, але і на світовому ринку. Забезпечення кожного 3 варіантів потребує особливого набору інструментів державного регулювання.

Висновки 3 проведеного дослідження. На основі вивчення теоретикометодологічного базису стратегічного державного управління з'ясовано, що державне стратегічне управління інноваційним розвитком транспортної інфраструктури - це науково обгрунтований вплив керівників держави, апарату державного управління на соціально-економічне середовище транспортного комплексу та інноваційну систему країни, що забезпечує якість і конкурентоспроможність транспортних послуг та сталий розвиток транспортного сектора економіки. Розкриті підходи, принципи i етапи реалізації державного стратегічного управління інноваційним розвитком транспортної інфраструктури, встановлені ознаки і сутність інноваційної стратегії як ключового елемента в системі стратегічного управління. Проведено систематизацію видів інноваційних стратегій і удосконалено їх класифікацію в залежності від поєднання комплексу ознак (корисність результату, тип інновацій, характер дій), що дозволило виділити такі види (і підвиди) стратегій як деструктивні (псевдо- i квазіінноваційні) i конструктивні (реактивну, оптимізаційну, прогресивну).

\section{Перелік посилань:}

1. Aaker D., Moorman Ch. "Strategic Market Management". 11th edn. Wiley. URL: https://www.perlego.com/book/2237417/strategic-market-managementpdf (дата звернення: 15.09.2021).

2. King W., Cleland D. Strategic planning and management. Van Nostrand Reinhold Co, 1987. 644 p.

3. Mintzberg H., Lampel J., Ahlstrand B. Strategy Safari: A Guided Tour Through the Wilds of Strategic Management. Free Press, 2005. 416 p.

4. Thompson A., Peteraf M., Gamble J., Strickland A. Crafting \& Executing Strategy: The Quest for Competitive Advantage: Concepts and Cases. McGraw-Hill Education; 21st edition, 2017. 912 p.

5. Дикань В. Л., Зубенко В. О., Маковоз О. В., Токмакова І. В., Шраменко О. В. Стратегічне управління: навч. посібник. К.: «Центр учбової літератури», 2013.272 c.

6. Дикань О. В., Смаль О. В. Стратегічний менеджмент та його 
використання в практиці формування і досягнення цілей розвитку залізничного транспорту. Вісник економіки транспорту і промисловості. 2017. Вип. 59. C. $230-235$.

7. Корінь М. В. Розвиток інфраструктури залізничного транспорту в умовах транскордонного співробітництва: монографія. Х.: УкрДУЗТ, 2019. $401 \mathrm{c}$.

8. Криворучко О. М., Водолажська Т. О. Методичні положення розробки стратегій за типами та цілями кадрової політики. Економіка транспортного комплексу. 2016. Вип. 27. С. 29-41.

9. Овчиннікова В. О. Стратегічне управління розвитком залізничного транспорту України: монографія. Х.: УкрДУЗТ, 2017. 427 с.

10. Овчиннікова В. О., Українська Л. О., Гонтар Н. О., Мірошніков П. В. Проблеми та пріоритети розвитку залізничного транспорту України. Вісник економіки транспорту та промисловості. 2019. № 67. С. 155-163.

11. Шинкаренко В. Г., Левченко О. П. Формирование стратегии развития автотранспортного предприятия: монография. Харьков: ХНАДУ, 2009. 166 с.

12. Яновська В. П., Гарматюк Н. В. Сучасні стратегії розвитку залізничного транспорту України. Збірник наукових праџь ДУІТ. Сер. : Економіка і управління. 2018. Вип. 2 (42). С. 114-123.

13. Вишневский А. С. Общая теория стратегирования: от парадигмы к практике использования: монография. НАН Украины, Ин-т экономики пром.сти. Киев, 2018. 168 с.

14. Бардовский В. П., Плахова Л. В., Соколова Н. Н. Актуальные вопросы формирования системы государственного стратегического управления. Фундаментальные исследования. 2016. № 8-2. С. 306-309.

15. Горбулін В. П., Качинський А. Б. Стратегічне планування: вирішення проблем національної безпеки: монографія. К.: НІСД, 2010. 288 с.

16. Гальчинський А., Геєць В., Семиноженко В. Інноваційна стратегія українських реформ. К.: Знання України, 2002.336 с.

17. Запровадження стратегічного планування в Україні: зб. документів і матеріалів / укл. В. Тертичка. К.: Центр досліджень адміністративної реформи НАДУ, 2004. $401 \mathrm{c}$.

18. Василенко В. О., Шматько В. Г. Інноваційний менеджмент. К. : ЦУЛ, Фенікс, 2003. 440 с.

19. Мудрова С. В. Инновационная деятельность - стратегия развития предприятий. Вестник Академии. Вопросы предпринимательства и экономики. 2011. № 4. C. 45-48.

20. Зянько В. В., Зянько В. В. Механізм формування інноваційної стратегії підприємства. Актуальні проблеми розвитку економіки регіону. 2010. Вип. 6. Т. 1. С. 24-30.

21. Краснокутська Н. В. Інноваційний менеджмент: навч. посібник. К.: KHEУ, 2003. 504 c.

22. Родионова Е. В. Инновационные стратеги предприятий. Наука $и$ экономика. 2011. № 3 (7). С. 36-38. 
23. Санто Б. Сила инновационного саморазвития. Инновации. 2004. № 2. C. $5-15$.

24. Юринець 3. В. Формування інноваційних стратегій: теорія, методологія, практика. Львів: СПОЛОМ, 2016. 412 с.

25. Dodgson M., Gann D., Salter A. The Management of Technological Innovation: Strategy and Practice; 2nd ed. Oxford University Press, 2008. 408 p.

26. Радинський С. Класифікація інноваційних стратегій підприємства. Сочіально-економічні проблеми і держава. 2013. Вип. 2 (9). С. 277-285.

27. Федулова I. В. Класифікація інноваційних стратегій. Теорії мікро- та макроекономіки: збірник наукових пращьь Академії муніципального господарства. 2010. № 35. С. 122-130.

28. Белов С. А. Классификация и критерии выбора инновационной стратегии высокотехнологичной промышленности. Экономические науки. 2016. № 134. С. $88-91$.

29. Порецкова К. В. Классификация инновационных стратегий промышленных предприятий. Современные проблемы науки и образования. 2013. № 2. C. 380.

30. Fridmen K. The Economics of industrial innovation; 2nd edn. Frances Pinter, London, 1982. P. 38.

31. Чубай В. М. Суть і види інноваційних стратегій машинобудівних підприємств. Бюлетень Міжнародного Нобелівського економічного форуму. T.2. 2010. № 1 (3). С. 347-356.

32. Кірдіна О. Г. Методологічні аспекти інвестиційно-інноваційного розвитку залізничного комплексу України: монографія. Х.: УкрДАЗТ, 2011. 312 c.

33. Лігузова В. О., Баклаженко Ю. В., Гиря Р. М. Світовий досвід підтримки інновацій. Миколаївський національний університет імені В.О. Сухомлинського. 2017. № 18. С. 36-41.

\section{References:}

1. Aaker, D. and Moorman, C. (2017). Strategic Market Management. 11th edn. Wiley, available at: https://www.perlego.com/book/2237417/strategic-marketmanagement-pdf (last accessed 15.09.2021).

2. King, W., Cleland, D. (1987). Strategic planning and management handbook. Van Nostrand Reinhold Co, 644 p.

3. Mintzberg, H., Lampel, J., Ahlstrand, B. (2005). Strategy Safari: A Guided Tour Through the Wilds of Strategic Management. Free Press, 416 p.

4. Thompson, A., Peteraf, M., Gamble, J., Strickland, A. (2017). Crafting \& Executing Strategy: The Quest for Competitive Advantage: Concepts and Cases. McGraw-Hill Education; 21st edition, 912 p.

5. Dykan, V. L., Zubenko, V. O., Makovoz, O. V., Tokmakova, I. V., Shramenko, O. V. (2013). Strategic management [Stratehichne upravlinnia]: tutorial. K.: «Tsentr uchbovoi literatury», $272 \mathrm{p}$.

6. Dykan, O. V., Smal, O. V. (2017). Strategic management and its use in the practice of forming and achieving the goals of railway transport development 
[Stratehichnyi menedzhment ta yoho vykorystannia $\mathrm{v}$ praktytsi formuvannia i dosiahnennia tsilei rozvytku zaliznychnoho transportu], Bulletin of Transport Economics and Industry, No. 59, P. 230-235.

7. Korin, M. V. (2019). Development of railway transport infrastructure in the conditions of cross-border cooperation [Rozvytok infrastruktury zaliznychnoho transportu $v$ umovakh transkordonnoho spivrobitnytstva]: monograph. Kh.: UkrDUZT, $401 \mathrm{p}$.

8. Kryvoruchko, O. M., Vodolazhska, T. O. (2016). Methodological provisions for the development of strategies by types and objectives of personnel policy [Metodychni polozhennia rozrobky stratehii za typamy ta tsiliamy kadrovoi polityky], Economics of the transport complex, No. 27, P. 29-41.

9. Ovchynnikova, V. O. (2017). Strategic management of railway transport development of Ukraine [Stratehichne upravlinnia rozvytkom zaliznychnoho transportu Ukrainy]: monograph. Kh.: UkrDUZT, 427 p.

10. Ovchynnikova, V. O., Ukrainska, L. O., Hontar, N. O., Miroshnikov, P. V. (2019). Problems and priorities of railway transport development in Ukraine [Problemy ta priorytety rozvytku zaliznychnoho transportu Ukrainy], Bulletin of Transport Economics and Industry, No. 67, P. 155-163.

11. Shinkarenko, V. G., Levchenko, O. P. (2009). Formation of the development strategy of the motor transport enterprise [Formirovanie strategii razvitiya avtotransportnogo predpriyatiya]: monograph, Kharkov: KhNADU, $166 \mathrm{p}$.

12. Yanovska, V. P., Harmatiuk, N. V. (2018). Modern strategies for the development of railway transport in Ukraine [Suchasni stratehii rozvytku zaliznychnoho transportu Ukrainy], Collection of scientific works of DUIT. Ser.: Economics and Management, No. 2 (42), P. 114-123.

13. Bishnevskiy, A. S. (2018). General theory of strategizing: from paradigm to practice of use [Obshchaya teoriya strategirovaniya: ot paradigmy $k$ praktike ispol'zovaniya]: monograph / NAS of Ukraine, Institute of Industrial Economics, Kiev, 168 p.

14. Bardovskiy, V. P., Plakhova, L. V., Sokolova, N. N. (2016). Topical issues of formation of the system of state strategic management [Aktual'nye voprosy formirovaniya sistemy gosudarstvennogo strategicheskogo upravleniya]. Basic research, No. 8-2, P. 306-309.

15. Horbulin, V. P., Kachynskyi, A. B. (2010). Strategic planning: solving problems of national security [Stratehichne planuvannia: vyrishennia problem natsionalnoi bezpeky]: monograph, K.: NISD, 288 p.

16. Halchynskyi, A., Heiets, V., Semynozhenko, V. (2002). Innovative strategy of Ukrainian reforms [Innovatsiina stratehiia ukrainskykh reform], K.: Knowledge of Ukraine, $336 \mathrm{p}$.

17. Introduction of strategic planning in Ukraine: coll. documents and materials [Zaprovadzhennia stratehichnoho planuvannia v Ukraini: zb. dokumentiv i materialiv] / incl. V. Tertichka. K.: Center for Research of Administrative Reform of NAPA, 2004, $401 \mathrm{p}$.

18. Vasylenko, V. O., Shmatko, V. H. (2003). Innovation management 
[Innovatsiinyi menedzhment], K.: TsUL, Feniks, 440 p.

19. Mudrova, S. V. (2011). Innovative activity - a strategy for the development of enterprises [Innovacionnaja dejatel'nost' - strategija razvitija predprijatij]. Academy Bulletin. Business and economic issues, No. 4, P. 45-48.

20. Zianko, V. V., Zianko, V. V. (2010). Mechanism of the formulation of the innovative strategy of the enterprise [Mekhanizm formuvannia innovatsiinoi stratehii pidpryiemstva], Actual problems of development of the economy of the region, No. 6 , Vol. 1, P. 24-30.

21. Krasnokutska, N. V. (2003). Innovation management [Innovatsiinyi menedzhment]: tutorial, K.: KNEU, 504 p.

22. Rodionova, E. V. (2011). Innovative strategists of enterprises [Innovacionnye strategi predprijatij], Science and economics, No. 3 (7), P. 36-38.

23. Santo, B. (2004). Power of innovative self-development [Sila innovacionnogo samorazvitija]. Innovation, No. 2, P. 5-15.

24. Iurynets, Z. V. (2016). Formation of innovation strategies: theory, methodology, practice [Formuvannia innovatsiinykh stratehii: teoriia, metodolohiia, praktyka], Lviv: SPOLOM, $412 \mathrm{p}$.

25. Dodgson, M., Gann, D., Salter, A. (2008). The Management of Technological Innovation: Strategy and Practice; 2nd ed. Oxford University Press, 2008. 408 p.

26. Radynskyi, S. (2013). Classification of innovative strategies of the enterprise [Klasyfikatsiia innovatsiinykh stratehii pidpryiemstva], Socio-economic problems and the state, No. 2 (9), P. 277-285.

27. Fedulova, I. V. (2010). Classification of innovation strategies [Klasyfikatsiia innovatsiinykh stratehii], Theories of micro- and macroeconomics: a collection of scientific works of the Academy of Municipal Economy, No. 35, P. 122130.

28. Belov, S. A. (2016). Classification and criteria for choosing an innovative strategy for high-tech industry [Klassifikacija i kriterii vybora innovacionnoj strategii vysokotehnologichnoj promyshlennosti], Economic sciences, No. 134, P. 88-91.

29. Poreckova, K. V. (2013). Classification of innovative strategies of industrial enterprises [Klassifikacija innovacionnyh strategij promyshlennyh predprijatij], Modern problems of science and education, No. 2, P. 380.

30. Fridmen, K. (1982). The Economics of industrial innovation; 2nd edn. Frances Pinter, London, P. 38.

31. Chubai, V. M. (2010). The essence and types of innovative strategies of machine-building enterprises [Sut i vydy innovatsiinykh stratehii mashynobudivnykh pidpryiemstv], Bulletin of the International Nobel Economic Forum, № 1 (3), Vol. 2, P. 347-356.

32. Kirdina, O.H. (2011). Methodological aspects of investment and innovation development of the railway complex of Ukraine [Metodolohichni aspekty investytsiino-innovatsiinoho rozvytku zaliznychnoho kompleksu Ukrainy]: monograph, H.: UkrDAZT, $312 \mathrm{p}$.

33. Lihuzova, V. O., Baklazhenko, Yu. V., Hyria, R. M. (2017). World 
experience in supporting innovation [Svitovyi dosvid pidtrymky innovatsii], Mykolayiv National University named after VO Sukhomlinsky, No.18, P. 36-41.

\section{РЕФЕРАТИ РЕФЕРАТЫ ABSTRACTS}

УДК 339.187; JEL Classification: М29

Дмитрієва О.I., Тімров О.О. СТРАТЕГІЧНЕ ДЕРЖАВНЕ УПРАВЛІННЯ ІННОВАЦІЙНИМ РОЗВИТКОМ ТРАНСПОРТНОЇ ІНФРАСТРУКТУРИ

Мета. Визначення підходів, принципів і етапів реалізації державного стратегічного управління інноваційним розвитком транспортної інфраструктури; розроблення типізації інноваційних стратегій на основі встановлення ознак і сутності інноваційної стратегії як ключового елемента в системі стратегічного управління. Методика дослідження. Теоретичною і методологічною основою є праці провідних вітчизняних і зарубіжних ученихекономістів, в яких розглядаються питання стратегічного державного управління та напрями інноваційного розвитку транспортної інфраструктури. В роботі використано методи узагальнення та абстрагування; метод аналізу i синтезу. Результати. В умовах ринкової економіки, що характеризується зростаючою невизначеністю розвитку зовнішнього середовища, неповнотою і асиметрією інформації, періодами підйому і спаду економічного розвитку, особлива увага приділяється формуванню системи державного стратегічного управління інноваційним розвитком транспортної інфраструктури. Державне стратегічне управління інноваційним розвитком транспортної інфраструктури це науково обгрунтований вплив керівників держави, апарату державного управління, політичних і громадських організацій на соціально-економічне середовище транспортного комплексу та інноваційної системи країни, що забезпечує якість і конкурентоспроможність транспортних послуг та сталий розвиток транспортного сектора економіки. В ході дослідження систематизовано основні концептуальні підходи теорії управління, напрямки державного стратегічного управління, принципи стратегічного управління інноваційним розвитком транспортної інфраструктури. У роботі визначено основні елементи ефективної системи стратегічного державного управління, запропоновано етапи i складові стратегічного управління інноваційним розвитком. На основі накопиченого досвіду у науковій літературі авторами представлено класифікацію інноваційних стратегій. Беручи до уваги накопичений досвід у статті розроблено класифікацію стратегій інноваційного розвитку транспортної інфраструктури, що враховує комплекс пріоритетних критеріїв (направленість результату, тип інновацій, характер дій). Наукова новизна. Удосконалено теоретичні основи стратегічного державного управління інноваційним розвитком транспортної інфраструктури, які, на відміну від відомих, включають типізацію інноваційних стратегій за комплексом ознак (корисність результату, тип інновацій, характер дій), що передбачає їх поділ на деструктивні (псевдо- і квазіінноваційні) і конструктивні (адаптивні, оптимізаційні, прогресивні) стратегії. Практична значущість. 
Запропоновані в статті теоретичні висновки, підходи і рекомендації можуть бути використані для розроблення стратегії інноваційного розвитку транспортної інфраструктури України і дозволять сформувати ефективний інструментарій державного регулювання інноваційних проєктів розвитку інфраструктури транспорту.

Ключові слова: стратегічне державне управління; інноваційний розвиток; транспортна інфраструктура; інноваційні стратегії; типізацію стратегій.

УДК 339.187; JEL Classification: M29

Дмитриева О.И., Тимров А.А. СТРАТЕГИЧЕСКОЕ ГОСУДАРСТВЕННОЕ УПРАВЛЕНИЕ ИННОВАЦИОННЫМ РАЗВИТИЕМ ТРАНСПОРТНОЙ ИНФРАСТРУКТУРЫ

Цель. Определение подходов, принципов и этапов реализации государственного стратегического управления инновационным развитием транспортной инфраструктуры; разработка типизации инновационных стратегий на основе установления признаков и сущности инновационной стратегии как ключевого элемента в системе стратегического управления. Методика исследования. Теоретической и методологической основой являлись работы ведущих отечественных и зарубежных ученых-экономистов, в которых рассматриваются вопросы стратегического государственного управления и направления инновационного развития транспортной инфраструктуры. В работе использованы методы обобщения и абстрагирования; метод анализа и синтеза. Результаты. В условиях рыночной экономики, характеризующейся растущей неопределенностью развития внешней среды, неполнотой и асимметрией информации, периодами подъема и спада экономического развития, особое внимание уделяется формированию системы государственного стратегического управления инновационным развитием транспортной инфраструктуры. Государственное стратегическое управление инновационным развитием транспортной инфраструктуры - научно обоснованное влияние руководителей государства, аппарата государственного управления, политических и общественных организаций на социальноэкономическую среду транспортного комплекса и инновационной системы страны, что обеспечивает качество и конкурентоспособность транспортных услуг и устойчивое развитие транспортного сектора экономики. В ходе исследования систематизированы основные концептуальные подходы теории управления, направления государственного стратегического управления, принципы стратегического управления инновационным развитием транспортной инфраструктуры. В работе определены основные элементы эффективной системы стратегического государственного управления, предложены этапы и составляющие стратегического управления инновационным развитием. На основе накопленного опыта в научной литературе авторами представлена классификация инновационных стратегий. Принимая во внимание накопленный опыт в статье, разработана классификация стратегий инновационного развития транспортной инфраструктуры, учитывающая комплекс приоритетных критериев (направленность результата, 
тип инноваций, характер действий). Научная новизна. Усовершенствованы теоретические основы стратегического государственного управления инновационным развитием транспортной инфраструктуры, которые, в отличие от известных, включают типизацию инновационных стратегий по комплексу признаков (полезность результата, тип инноваций, характер действий), что предполагает их разделение на деструктивные (псевдо- и квазиинновационные) и конструктивные (адаптивные, оптимизационные, прогрессивные) стратегии. Практическая значимость. Предложенные в статье теоретические выводы, подходы и рекомендации могут использоваться для разработки стратегии инновационного развития транспортной инфраструктуры Украины и позволят сформировать эффективный инструментарий государственного регулирования инновационных проектов развития инфраструктуры транспорта.

Ключевые слова: стратегическое государственное управление; инновационное развитие; транспортная инфраструктура; инновационные стратегии; типизацию стратегий.

\section{UDK 339.187; JEL Classification: M29}

\section{Dmytriieva O.I., Timrov O.O. STRATEGIC PUBLIC} ADMINISTRATION OF TRANSPORT INFRASTRUCTURE INNOVATIVE DEVELOPMENT

Purpose: The purpose is specifying the approaches, principles and stages of putting into practice the strategic public administration of transport infrastructure innovative development; working out typification of innovation strategies based on determining the features and essence of innovation strategy as a key element in the system of strategic management. Methodology of research. The theoretical and methodological basis is the works of leading domestic and foreign economists, that address the issues of strategic public administration and areas of innovative development of transport infrastructure. The methods of generalization and abstraction and the method of analysis and synthesis are used in the work. Findings. In a market economy, characterized by growing uncertainty in the development of the external environment, incompleteness and asymmetry of information, periods of ups and downs of economic development, special attention is paid to the formation of a system of strategic public administration of innovative transport infrastructure. Strategic public administration of transport infrastructure innovative development is a scientifically substantiated influence of the heads of state, public administration, political and public organizations on the socio-economic environment of the transport complex and innovation system, which ensures quality and competitiveness of transport services and sustainable development of the transport sector. In the course of the research the main conceptual approaches of the theory of management, directions of the strategic public administration, principles of strategic management of transport infrastructure innovative development are systematized. The main elements of the effective system of strategic public administration are determined in the work, the stages and components of the strategic management of innovative development are offered. Based on the experience gained in the scientific literature, the authors present a classification of innovation strategies. Taking into account the 
accumulated experience, the article develops a classification of strategies for innovative development of transport infrastructure, which takes into account a set of priority criteria (the direction of the result, the type of innovation, the nature of action). Originality. Theoretical bases of strategic public administration of transport infrastructure innovative development are improved. They, as opposed to the known ones, include typification of innovation strategies by a set of features (the usefulness of result, the type of innovations, the nature of actions), which provides their division into destructive (pseudo- and quasi-innovative) and constructive (adaptive, optimization, progressive) strategies. Practical value. The theoretical conclusions, approaches and recommendations offered in the article can be used for elaborating the strategy of innovative development of transport infrastructure in Ukraine and will make it possible to form the effective tools for the state regulation of innovative projects of transport infrastructure development.

Key words: strategic public administration; innovative development; transport infrastructure; innovation strategies; typification of strategies.

\section{Відомості про авторів / Сведения об авторах / About the Authors}

Дмитрієва Оксана Іллівна - доктор економічних наук, доцент, Харківський національний автомобільно-дорожній університет, завідувачка кафедри економіки i підприємництва, м. Харків, Україна; e-mail: oksanahnadu@gmail.com; ORCID: https://orcid.org/0000-0001-9314-350X. Моб. 063-353-79-98.

Дмитриева Оксана Ильинична - доктор экономических наук, доцент, Харьковский национальный автомобильно-дорожный университет, заведующая кафедры экономики и предпринимательства, г. Харьков, Украина.

Dmytriieva Oksana - DSci in Economics, Associate Professor, Kharkov National Automobile and Highway University, Head of the Department of Economics and Business, Kharkiv, Ukraine.

Тімров Олексій Олександрович - молодший науковий співробітник, Науково-дослідний, проектно-конструкторський та технологічний інститут мікрографії. м. Харків, Україна; e-mail: alexey.fril @gmail.com; ORCID: https://orcid.org/0000-0002-8781-3527. Моб. 097-315-04-82.

Тимров Алексей Александрович - младший научный сотрудник, Научноисследовательский, проектно-конструкторский и технологический институт микрографии. г. Харьков, Украина

Timrov Oleksii - Junior Researcher, Research, Design and Technological Institute of Micrography, Kharkiv, Ukraine 